\title{
Infection and upregulation of proinflammatory cytokines in human brain vascular pericytes by human cytomegalovirus
}

\author{
Donald J Alcendor ${ }^{*}$, Ashley M Charest, Wen Qin Zhu, Hollie E Vigil and Susan M Knobel
}

\begin{abstract}
Background: Congenital human cytomegalovirus (HCMV) infections can result in CNS abnormalities in newborn babies including vision loss, mental retardation, motor deficits, seizures, and hearing loss. Brain pericytes play an essential role in the development and function of the blood-brain barrier yet their unique role in HCMV dissemination and neuropathlogy has not been reported.
\end{abstract}

Methods: Primary human brain vascular pericytes were exposed to a primary clinical isolate of HCMV designated 'SBCMV'. Infectivity was analyzed by microscopy, immunofluorescence, Western blot, and qRT-PCR. Microarrays were performed to identify proinflammatory cytokines upregulated after SBCMV exposure, and the results validated by real-time quantitative polymerase chain reaction (qPCR) methodology. In situ cytokine expression of pericytes after exposure to HCMV was examined by ELISA and in vivo evidence of HCMV infection of brain pericytes was shown by dual-labeled immunohistochemistry.

Results: HCMV-infected human brain vascular pericytes as evidenced by several markers. Using a clinical isolate of HCMV (SBCMV), microscopy of infected pericytes showed virion production and typical cytomegalic cytopathology. This finding was confirmed by the expression of major immediate early and late virion proteins and by the presence of HCMV mRNA. Brain pericytes were fully permissive for CMV lytic replication after 72 to 96 hours in culture compared to human astrocytes or human brain microvascular endothelial cells (BMVEC). However, temporal transcriptional expression of pp65 virion protein after SBCMV infection was lower than that seen with the HCMV Towne laboratory strain. Using RT-PCR and dual-labeled immunofluorescence, proinflammatory cytokines CXCL8/LL-8, CXCL11/ITAC, and CCL5/Rantes were upregulated in SBCMV-infected cells, as were tumor necrosis factor-alpha (TNF-alpha), interleukin-1 beta (IL-1 beta), and interleukin-6 (IL-6). Pericytes exposed to SBCMV elicited higher levels of IL-6 compared to both mock-infected as well as heat-killed virus controls. A 6.6-fold induction of IL-6 and no induction TNF-alpha was observed in SBCMV-infected cell supernatants at 24 hours postinfection. Using archival brain tissue from a patient coinfected with HCMV and HIV, we also found evidence of HCMV infection of pericytes using dual-label immunohistochemistry, as monitored by NG2 proteoglycan staining.

Conclusion: HCMV lytic infection of primary human brain pericytes suggests that pericytes contribute to both virus dissemination in the CNS as well as neuroinflammation.

Keywords: Cytomegalovirus, pericytes, astrocytes, BMVECs, neuroinflammation, blood-brain barrier, virus replication, cytokines

\footnotetext{
* Correspondence: dalcendor@mmc.edu

Department of Microbiology and Immunology, Center for AIDS Health

Disparities Research, Meharry Medical College, School of Medicine, 1005 Dr.

D.B. Todd Jr. Blvd, Nashville, TN 37208-3599, USA
} 


\section{Background}

Human cytomegalovirus (HCMV) is a ubiquitous pathogen and is the most common infectious cause of congenital disease [1-4]. Congenital infections caused by HCMV represent the leading infectious cause of mental retardation and deafness in children [5,6]. Other abnormalities in newborns include vision loss, motor deficits, seizures, and sensorineural hearing loss [7-9]. With only 10 to $15 \%$ of children presenting with symptomatic disease at birth, HCMV can also result in long-term progressive neuropathology in children who are asymptomatic at birth. It is estimated that approximately 8,000 children are affected each year in the United States with some form of neuropathology associated with a cytomegalovirus (CMV) congenital infection [7]. In addition, HCMV, a common opportunistic infection in patients with HIV/AIDS [10], is often found in brain tissue from these patients [11] where it can be associated with cytomegalovirus-induced encephalitis $[12,13]$.

The blood-brain barrier (BBB) interfaces the peripheral circulation and the central nervous system (CNS) allowing nutrients into the CNS and preventing bloodborne pathogens from harming the brain. This barrier is an elaborate network of tight junctions (TJ) between capillary endothelial cells that lack fenestrae and have a reduced capacity for pinocytosis $[14,15]$. The TJ of the capillary endothelium is supported by astrocytic endfeet and pericytes. Cerebral vascular pericytes (CNS pericytes) have been shown to enhance TJ barrier function, stimulate expression of $\mathrm{TJ}$ proteins and reduce the paracellular permeability of the capillary endothelium [1619]. Pericytes are adult multipotent, contractile and migratory stem cells $[20,21]$ that surround capillaries and actively communicate with other cells of the neurovasculature, including endothelial cells, astrocytes and neurons. Completely surrounded by a basal lamina, they also contribute to the deposition of the basal lamina during vascular development and angiogenesis [22]. Although a critical cellular component for the development and function of the $\mathrm{BBB}$, the role of pericytes in HCMV infection and dissemination has largely been ignored [23]. Rather, to date, astrocytes and brain microvascular endothelial cells (BMVEC) cells have been implicated as cell types that support HCMV dissemination at the blood-brain barrier level [7].

To our knowledge, no studies have reported on the interaction between human cytomegalovirus and brain vascular pericytes. However in 1990, Price et al. [24] demonstrated murine CMV (MCMV) infection of pericytes in brown and white adipose tissue of young adult infected mice. These mice later developed viral-induced inflammatory lesions in peripancreatic and salivary gland adipose tissues. In the present study, we investigated the infectivity of human brain vascular pericytes by HCMV using a primary isolate from a child with disseminated HCMV disease. Infection was determined by monitoring pericytes for HCMV cytopathology using standard biochemical assays for viral proteins and viral mRNA. Proinflammatory cytokines expressed in exposed pericytes were identified by microarrays and confirmed by dual-labeled immunofluorescence and real-time PCR (qRT-PCR).

This is the first report to date that investigates the infectivity of human brain pericytes for HCMV and their role in viral dissemination in the CNS. It supports the postulate that pericytes are more permissive for CMV lytic replication compared to BMVEC or astrocytes, and that pericytes could serve as amplification reservoirs for HCMV. Finally, pericyte exposure to HCMV induced a proinflammatory cascade that likely contributes to neuroinflammation.

\section{Methods}

\section{Cells and viruses}

The primary isolate (termed SBCMV) was provided by Dr. Ravit Arav-Boger, Johns Hopkins University, and obtained from the urine of a congenitally infected infant with disseminated HCMV disease. Institutional review board (IRB) exemption for the use of this isolate was given by Johns Hopkins Hospital. Primary human brain vascular pericytes and astrocytes were obtained from Cell Systems (Kirkland, WA, USA). Primary BMVEC cells were a kind gift from Dr. Milan Fiala (UCLA, Los Angeles, CA, USA) [25]. All cells were maintained at low passage in complete pericyte medium from ScienCell Corporation (Carlsbad, CA, USA). Cells were trypsinized and plated in uncoated $100 \mathrm{~cm}^{2}$ dishes or uncoated $4.2 \mathrm{~cm}^{2} /$ well glass chamber slides at a density $1 \times 10^{6}$ and $2.5 \times 10^{5}$ cells per dish and well, respectively. Heat-killed SBCMV was prepared by heating the viral inoculum to $65^{\circ} \mathrm{C}$ for 30 minutes in a water bath [26].

\section{Microarray analysis}

The GeneChip Human Genome U133 Plus 2.0 array (Affymetrix, Santa Clara, CA, USA) with complete coverage of the human genome containing over 47,000 transcripts was used to identify gene expression changes in primary human brain vascular pericytes three days postinfection. Several proinflammatory cytokines that were upregulated after SBCMV infection were selected for further study. A subgroup of genes identified as having the highest fold transcription levels associated with neuroinflammation were selected for qRT-PCR analysis.

\section{Cytomegalovirus infection of pericytes and RNA isolation}

Pericytes were infected with SBCMV at a multiplicity of infection (MOI) of 0.1 and virus adsorption was allowed for three hours, then the inoculum was removed and 
replaced with fresh media. Uninfected pericytes were used as mock-infected controls. Cultures were examined daily for evidence of cytopathology and at three days postinfection, cells were harvested, pelleted, and total RNA extracted at a density of $3 \times 10^{6}$ cells using an RNeasy Mini Kit (Qiagen, Valencia, CA, USA). Extracted RNA was treated with 0.4 units/ml of RNase-free DNase (Qiagen, Valencia, CA, USA). RNA purity was first determined by spectrophotometric analysis, then resuspended in RNase-free water at a concentration of $200 \mathrm{ng} / \mu \mathrm{l}$ and stored at $-80^{\circ} \mathrm{C}$. RNA quality was assessed using an Agilent 2100 bioanalyzer (Agilent Technologies, Santa Clara, CA, USA).

\section{Electron microscopy}

Three days postinfection, pericytes were washed twice in sodium cacodylate buffer $\mathrm{pH} 7.4$, fixed in $2.5 \%$ glutaraldehyde for one hour and held at $4{ }^{\circ} \mathrm{C}$ for an additional twenty-four hours. Monolayers were rinsed twice with $0.1 \mathrm{M}$ sodium cacodylate buffer ( $\mathrm{pH} 7.4$ ), fixed in $1 \%$ osmium tetraoxide for one hour, washed twice for five minutes in cacodylate buffer and dehydrated in graded ethanol. HCMV-infected pericytes were pelleted for 10 minutes at $1500 \mathrm{rpm}$ in a Sorvall Legend RT centrifuge (ThermoFisher Scientific, Waltham, MA, USA). Pellets were embedded in spur resin, sectioned for standard electron microscopy (EM) analysis and visualized on a Phillips CM12 electron microscope (Phillips Research, Eindhoven, The Netherlands).

\section{Western blot}

Cell extracts were prepared using RIPA lysis buffer [50 mM Tris pH 7.5, $150 \mathrm{mM} \mathrm{NaCl}, 2 \mathrm{mM}$ ethylenediaminetetraacetic acid (EDTA) pH 8.0, 1\% NP40, 0.5\% sodium deoxycholate, $0.1 \%$ sodium dodecyl sulfate (SDS), and proteinase inhibitor]. Lysates were placed on ice for 30 minutes and then clarified by centrifugation. Total protein was measured by bicinchoninic acid (BCA) assay (Pierce; ThermoFisher Scientific, Waltham, MA, USA). Fifteen $\mu \mathrm{g}$ of protein lysates from paired, mock and infected samples were fractionated in 4 to $20 \%$ SDSPAGE gels, transferred to nitrocellulose membranes, blocked with $5 \%$ milk, $0.1 \%$ TBST $(0.1 \%$ Tween 20,20 $\mathrm{mM}$ Tris, $150 \mathrm{mM} \mathrm{NaCl}$ ) and incubated at $4^{\circ} \mathrm{C}$ overnight with a monoclonal antibody to either major immediate early gene (MIE) (mAb 810 recognizes MIE IE1 and IE2, (Millipore, Temecula, CA, USA) or to human cytomegalovirus phosphorylated envelope protein expressed at late times during virus replication (pp65) (Vector Laboratories, Burlingame, CA, USA), both at a 1:2000 dilution. Membranes were washed five times in $0.1 \%$ TBST and incubated for one hour followed by incubation with a secondary antibody donkey anti-mouse peroxidase conjugate (Santa Cruz Biotech, Santa Cruz, CA,
USA) at a dilution of 1:10,000. Immunoreactive bands were detected with SuperSignal West Dura Extended Substrate (Pierce; ThermoFisher Scientific, Waltham, MA, USA) following exposure to X-ray film.

\section{RT-PCR}

Total RNA was extracted from SBCMV-infected pericytes and controls using a Qiagen RNeasy Mini Kit (Qiagen, Valencia, CA, USA). RNA was DNase-treated prior to elution on the column according to the manufacturer's recommendations. Messenger RNA in $1 \mu \mathrm{g}$ of each sample was primed using oligo-dT and reverse transcribed with a high-capacity cDNA reverse transcription kit (Applied Biosystems, Foster City, CA, USA). Gene-specific primer pairs included $\mathrm{C}$ chemokine (C-C motif) ligand 5/Rantes (CCL5/Rantes), chemokine (C-X-C motif) ligand 11/I-TAC (CXCL11/I-TAC), and (CXCL8/IL-8) and 10 to $200 \mathrm{ng}$ of cDNA for RT-PCR amplification, using PuReTaq Ready-To-Go PCR beads (GE Healthcare, Buckinghamshire, UK). PCR was carried out in a MJ Mini thermal cycler (Bio-Rad Laboratories, Hercules, CA, USA) in a final volume of $25 \mu$. The cycling protocol used was $95^{\circ} \mathrm{C}$ for five minutes, $55^{\circ} \mathrm{C}$ for thirty seconds, and $72^{\circ} \mathrm{C}$ for one minute for thirty-six cycles, with a final extension at $72^{\circ} \mathrm{C}$ for ten minutes. PCR products were electrophoresed in $1.5 \%$ agarose and DNA bands visualized by ethidium bromide. Primers for RT-PCR amplification were designated as: HCMV MIE 1 forward 5' -CCAAGCGGCCTCTGATAACCAAGCC-3', reverse 5'-CAGCACCATCCTCCTCTTCCTCTGG3' (exon 4, $435 \mathrm{bp}$ ); radical S-adenosyl methionine domaincontaining protein 2 (RSAD2) forward 5'-CTTTGTGCT GCCCCTTGAGGAA - 3', reverse 5'CTCTCCCGGAT CAGGCTTCCA3' (256 bp); CXCL8/IL-8 forward 5'-TG GGTGCAGAGGGTTGTG-3', reverse 5' -CAGACTAGG GTTGCCAGATTTA-3' (532 bp); CXCL11/I-TAC forward 5' - TTAAACAAACATGAGTGTGAAGGG-3', reverse 5' CGTTGTCCTTTATTTTCTTTCAGG-3 (228 bp); and CCL5/Rantes forward 5' - GGCAGCCCTCGCTGTCATC CTCA-3', reverse $5^{\prime}$-CTTGATGTGGGCACGGGGCA GTG-3'. Gyceralaldehyde phosphate dehydrogenase (GAPDH) forward 5' - TGATGACATCAAGAAGGTG GTGAA-3', reverse 5' ${ }^{\prime}$-TCCTTGGAGGCCATGTGGGC CAT-3' (256 bp) was amplified in mock and infected cells as a loading and quality control.

\section{Real-time qPCR}

Real-time PCR was performed in 96 well optical plates (Sorenson Bioscience, Inc., Salt Lake City, UT, USA) with cDNA using the MyiQ Single-Color Real-Time PCR Detection System (Bio-Rad Laboratories, Hercules, CA, USA) in $25 \mu \mathrm{l}$ reaction volumes. A master mix was made according to manufacturer's instructions using SYBR green supermix (Bio-Rad Laboratories, Hercules, 
CA, USA) or VeriQuest master mix (Affymetrix, Santa Clara, CA, USA) for amplification of high GC-content cDNAs. Forward and reverse primers were used at a concentration of $250 \mathrm{nM}$ per well, made in RNase/DNase-free $\mathrm{H}_{2} \mathrm{O}$. Primer sequences for qPCR were as follows: TNFalpha forward 5' - CAGAGGGAAGAGTTCCCCAG -3', reverse 5'-CCTTGGTCTGGTAGGAGACG- 3'; IL-1beta forward 5'-CAAATTCGGTACATCCTCGAC-3', reverse 5'- GTCAGGGGTGGTTATTGCATC-3'); and IL-6 forward 5' - AAACAGATGAAGTGCTCCTTCCAGG-3', reverse 5-TGGAGAACACCACTTGTTGCTCCA- 3'. The cDNAs from mock-infected and SBCMV-infected pericytes were diluted 1:3 using RNase/DNase-free $\mathrm{H}_{2} \mathrm{O} ; 3 \mu \mathrm{l}$ of this dilution was added to each well, and control wells substituted water for cDNA. The cycling sequence included $95^{\circ} \mathrm{C}$ for three minutes, $95^{\circ} \mathrm{C}$ for fifteen seconds, $60^{\circ} \mathrm{C}$ for one minute, $95^{\circ} \mathrm{C}$ for one minute, $55^{\circ} \mathrm{C}$ for one minute, and $55^{\circ} \mathrm{C}$ for thirty seconds for eighty-one total cycles. A GAPDH primer set was included for normalization. Data analysis was performed using Bio-Rad iQ5 optical system software version 2.0.

\section{Immunofluorescence}

Chamber slides containing either infected or uninfected cells were washed twice with phosphate buffer saline (PBS) $\mathrm{pH} 7.4$, air dried, and fixed in absolute methanol for 10 minutes. Cells were air dried for fifteen minutes, hydrated in Tris saline ( $\mathrm{pH}$ 7.4) for five minutes, and then incubated for one hour with monoclonal antibodies to the HCMV MIE at a 1:50 dilution (MIE, mAb 810, Millipore, Temecula, CA, USA) or the HCMV tegument protein pp65 (UL83) at 1:50 (Vector Laboratories, Burlingame, CA, USA). Dual-labeled immunofluorescence was performed using a mouse monoclonal to HCMV MIE and goat polyclonal antibodies at 1:100 dilution to human CXCL8/IL-8, CXCL11/I-TAC, and CCL5/Rantes purchased from R\&D Systems (Minneapolis, MN, USA). Glial fibrillary acid protein (GFAP), (Millipore, Temecula, CA, USA), von Willebrand factor (VWF) (Millipore, Temecula, CA, USA) and neuron-glial antigen 2 (NG2) proteogylcan (Santa Cruz Biotech, Santa Cruz, CA, USA) were used at a 1:50 dilution for immunofluorescent staining of astrocytes, brain microvascular endothelial cells (BMVEC) and pericytes, respectively. Cells were washed three times with Tris saline and then incubated at $37^{\circ} \mathrm{C}$ for thirty minutes with a combination of secondary donkey anti-mouse Immunoglobulin G (IgG) antibodies conjugated with rhodamine isothiocyanate (RITC), and donkey anti-goat antibody conjugated with fluroescein isothiocyanate (FITC), (Jackson ImmunoResearch, West Grove, PA, USA) at a 1:100 dilution in PBS. Cells were washed another three times in Tris saline and mounted with Vectashield mounting media (Burlingame, CA, USA) containing $1.5 \mu \mathrm{g} / \mathrm{ml}$ of 4',6-diamidino-2-phenylindole (DAPI). Fluorescence was
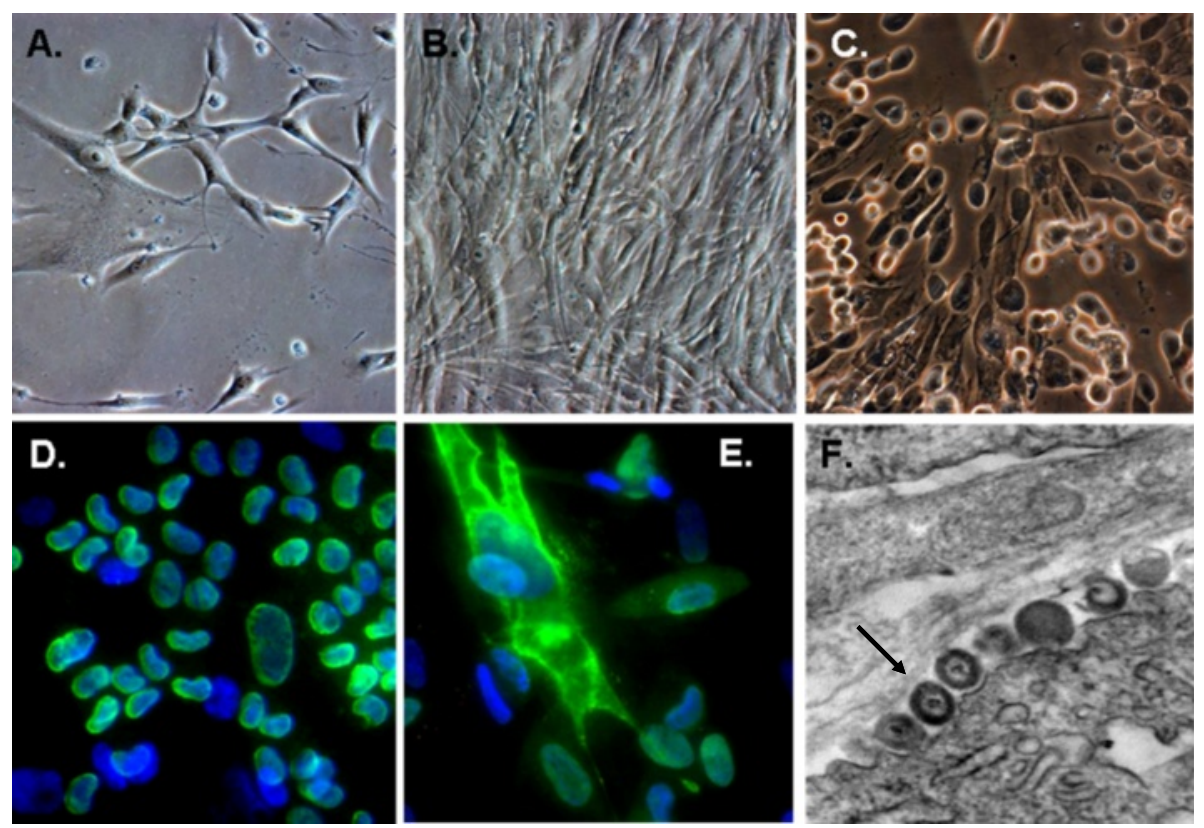

Figure 1 Primary brain vascular pericytes. Phase contrast images of: (A) an uninfected subconfluent monolayer of primary brain vascular pericytes, (B) a confluent monolayer of brain vascular pericytes, and (C) pericytes 72 hours after infection with SBCMV. Immunofluorescence staining of SBCMV-infected pericytes for (D) HCMV MIE protein and (E) pp65 late protein. (F) TEM of SBCMV-infected pericytes showing HCMV virions in the cytoplasm (see arrow). With the exception of the TEM, images were taken on a Nikon TE2000S microscope (200x magnification). HCMV, human cytomegalovirus; MIE, major immediate early protein; SBCMV, primary HCMV isolate from a patient; TEM, transmission electron microscopy. 
A.

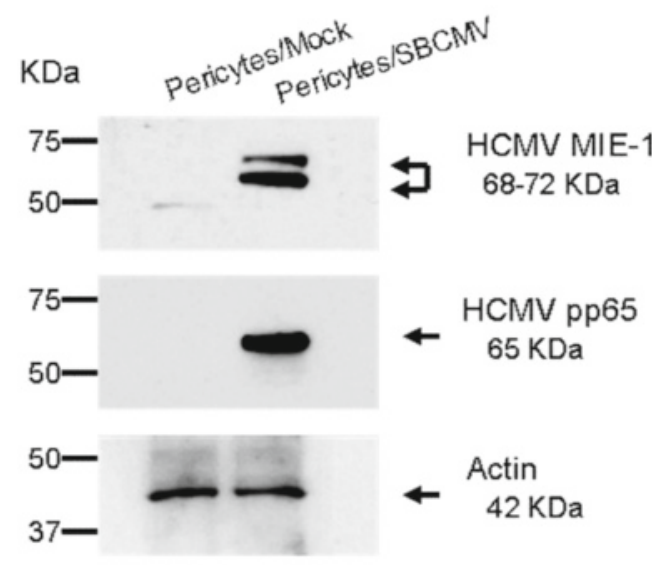

B.

Temporal Expression of the gene encoding HCMV pp65 virion protein by qRT-PCR in Infected Pericytes
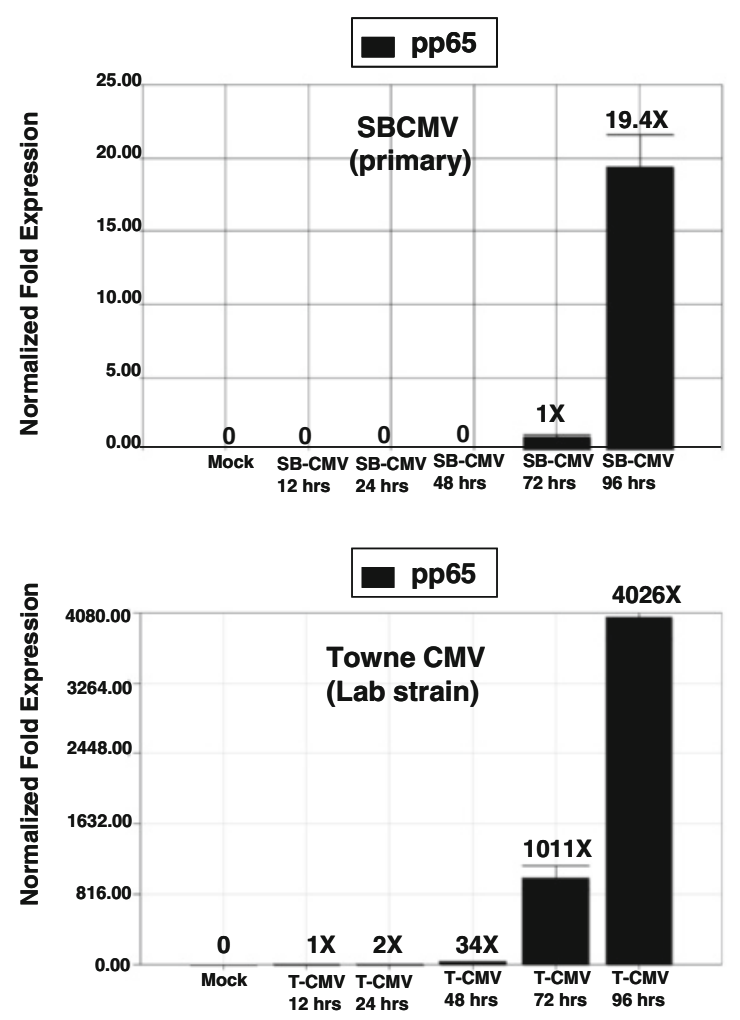

C.

RT-PCR Amplification of GAPDH and HCMV MIE-1 in mock and SBCMV Infected brain pericytes
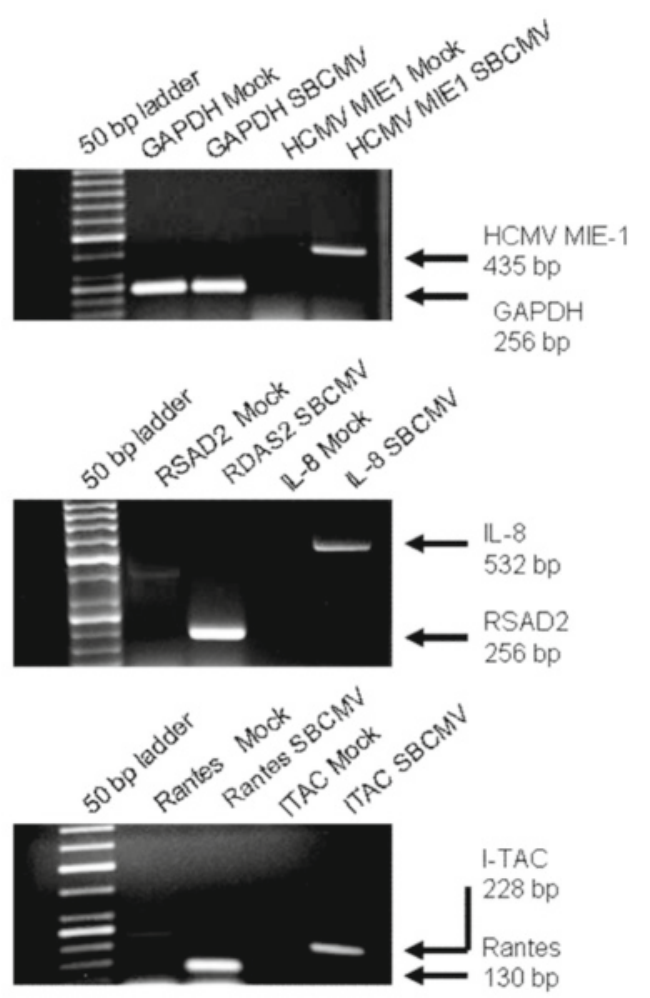

D.

Real-time RT-PCR Analysis for Chemotactic/ Proinflammatory Cytokines Rantes/CCL-5, ITAC/CXCL-11 and IL-8/CXCL-8 in Pericytes after SBCMV Infection

$\square$ Mock $\square$ sBcmv

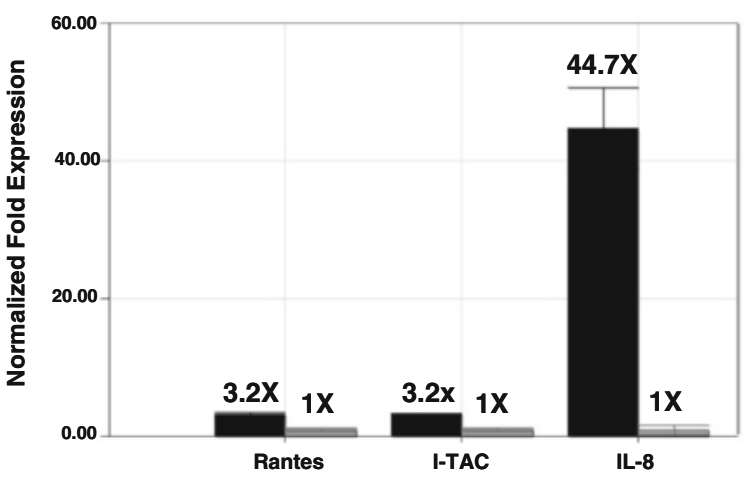


(See figure on previous page.)

Figure 2 Protein expression in mock- and SBCMV-infected brain pericytes. (A) Western blot showing expression of HCMV MIE and pp65 virion proteins in pericytes infected with SBCMV for 72 hours. Actin was the loading control. (B) Temporal expression of HCMV pp65 virion protein by real-time PCR in infected pericytes (SBCMV or Towne CMV) at 12, 24, 48, 72, and 96 hours postinfection. (C) Semi-quantitative RT-PCR for HCMV MIE, GAPDH, CXCL8/IL-8, RSAD2, CXCL11/I-TAC and CCL5/Rantes (72-hour exposure). GAPDH was the loading control. (D) Real time RT-PCR analysis for CCL5/Rantes, CXCL11/I-TAC, and CXCL8/IL-8 in pericytes 72 hours after SBCMV infection. This experiment was replicated three times, and amplifications were performed in triplicate and normalized to GAPDH. CCL5/Rantes, chemokine (C-C motif) ligand 5/Rantes;

CXCL8/IL-8, blood-brain barrier; CXCL11/I-TAC, chemokine (C-X-C motif) ligand 11/I-TAC; GAPDH, gyceralaldehyde phosphate dehydrogenase; HCVM, human cytomegalovirus; MIE, major immediate early protein: pp65, human cytomegalovirus phosphorylated envelop protein expressed at late times during virus replication; RSAD2, radical S-adenosyl methionine domain-containing protein 2; RT-PCR, reverse transcription polymerase chain reaction; SBCMV, primary HCMV isolate from a patient.

photographed with a Nikon TE $2000 \mathrm{~S}$ fluorescent microscope mounted with a charge-coupled device (CCD) camera (Nikon, Tokyo, Japan).

\section{Human cytokine ELISA}

The effects of HCMV exposure on pericyte expression of cytokines was measured with a human angiogenesis cytokine ELISA assay kit, profiling angiogenic cytokines (Signosis Sunnyvale, CA, USA). Mock-infected, pericytes exposed to heat-killed virus and SBCMV-infected pericytes were plated at a density of $5 \times 10^{5}$ cells in $10 \mathrm{~cm}$ dishes and grown to $90 \%$ confluence. Cell supernatants were then assayed for TNF-alpha, IL-6 and tumor growth factor-beta (TGF-beta), according to the manufacturer's protocol. Quantitative analysis of IL-6 and TNF-alpha secreted from SBCMV-infected pericyte supernatants after 24 hours were monitored using human TNFalpha and human IL-6 cytokine ELISA assays from Signosis according to the manufacturer's protocol.

\section{Immunohistochemistry}

Dual-labeled immunohistochemistry (IHC) was performed as previously described [27] Archival brain tissue from an HIV-infected patient was obtained from the Texas Repository for AIDS Neuropathogenesis Research (Galveston, TX, USA). Specimen use was HIPPA compliant and approved by the Meharry Medical College IRB. Brain tissue was histologically identified as positive for HIV and HCMV. Tissue was mounted on chemate slides, paraffin embedded and dual stained by IHC for HCMV MIE in combination with the pericyte marker NG2 proteoglycan (Abcam, Cambridge, MA, USA) [28].

\section{Statistical analysis}

Experiments presented in this study were performed in triplicate (CMV-exposed brain pericytes, astrocytes and BMVEC cell pellets were used for qRT-PCR, while parallel supernatants were pooled for the ELISA assay). Quantitative real-time PCR experiments were replicated three times and normalized to GAPDH.

\section{Results}

\section{Cytomegalovirus infection of pericytes}

Primary brain vascular pericytes exhibited characteristic long extensions of cytoplasm in subconfluent cultures (Figure 1A), appeared fibroblastic when confluent (Figure 1B), and had typical cytomegalic cytopathology three days postinfection with the SBCMV clinical isolate (Figure 1C). Pericytes supported full lytic replication of SBCMV, as more than $80 \%$ of cells were infected as demonstrated by the production of HCMV MIE 1 and 2 and the viral tegument protein pp65 (Figure 1D, E). These results were performed in triplicate using the same viral inoculum. Transmission electron microscopy (TEM) analysis revealed typical cytomegalovirus virions in SBCMVinfected pericytes three days postinfection (Figure 1F).

\section{Cytomegalovirus protein expression in pericytes and upregulation of proinflammatory cytokine proteins and mRNA}

Using Western blots, we observed HCMV MIE 1, 2 and the pp65 late virion protein expression in pericytes infected with SBCMV compared to mock-infected control cells (Figure 2A). Temporal expression of the gene encoding HCMV pp65 virion protein was determined by qRT-PCR in pericytes infected with either the SBCMV isolate or the Towne lab HCMV strain after 12, 24, 48, 72 , or 96 hours of incubation. With the SBCMV clinical isolate, we observed marginal expression of pp65 mRNA in infected pericytes beginning at 72 hours and a 19.4fold increase in pp65 mRNA at 96 hours postinfection compared to mock-infected controls (Figure 2B). With the Towne laboratory strain of HCMV we observed a 34-fold, 1,011-fold and a 4,026-fold increase in pp65 mRNA in infected pericytes at 48, 72, and 96 hours respectively (Figure 2B). By semi-quantitative real-time PCR we observed upregulation of IL-8, CXCL11/I-TAC, and CCL5/Rantes in SBCMV-infected pericytes compared to mock-infected control cells (Figure 2C). Transcriptional analysis by semi-quantitative RT-PCR revealed HCMV MIE 1 transcripts expressed in infected cells but not controls (Figure 2C). Using RT-PCR amplifications for proinflammatory cytokines CXCL8/IL-8, CXCL11/I-TAC, and 


\section{A.}

Dual Labell FA on SBCMV Infected Pericyte sex pressing CMVIE1 and IL-8
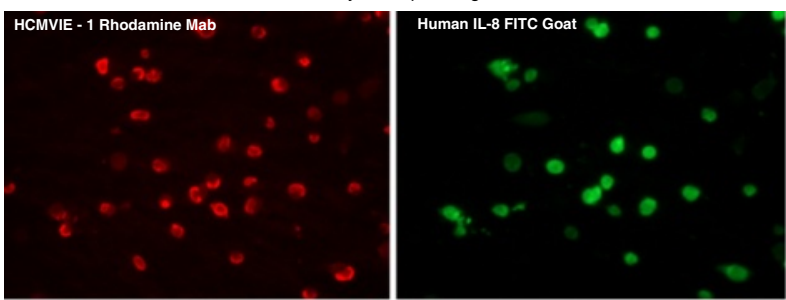

DAPI

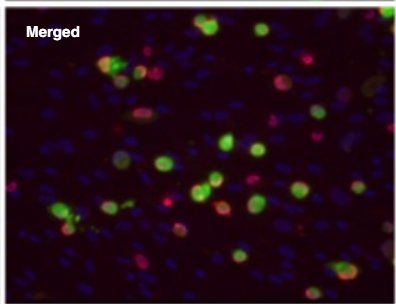

B.

IFA on SBCMV Infected Pericytes Expressing HCMV MIE and CXCL11/I-TAC
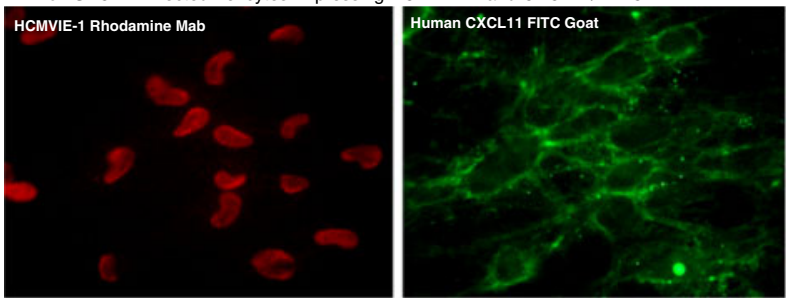

DAPI
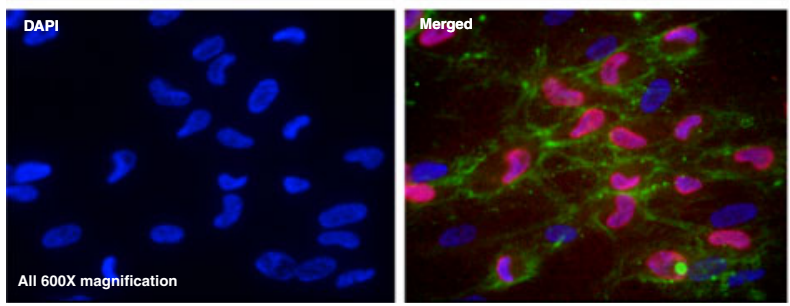

C.

IFA on SBCMV Infected Pericytes Expressing HCMV MIE and CCL-5 / Rantes
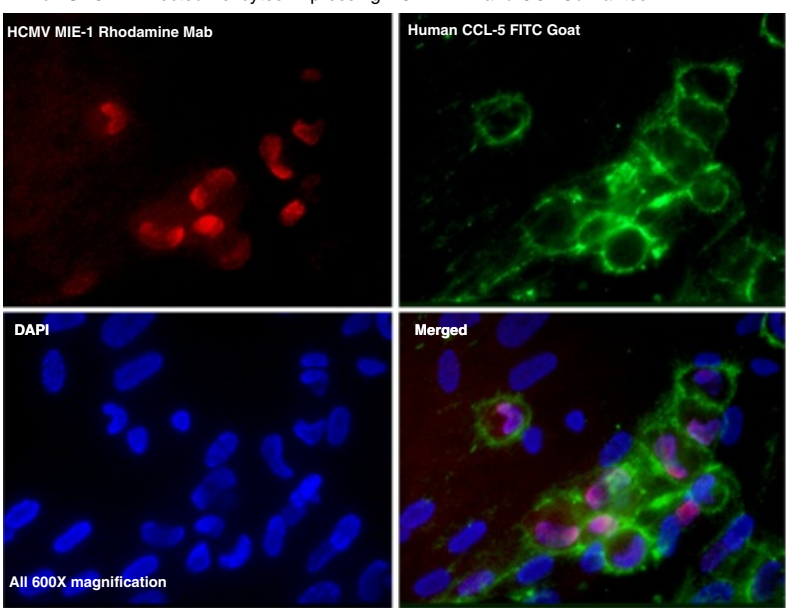

Figure $\mathbf{3}$ (See legend on next page.) 
(See figure on previous page.)

Figure 3 Dual-labeled immunofluorescent staining of SBCMV-infected pericytes showing colocalization (merged images) of proteins.

(A) Infected pericytes expressing MIE proteins and CXCL8/L-8. (B) Infected pericytes expressing MIE proteins and CXCL11/I-TAC. (C) Infected pericytes expressing MIE proteins and CCL5/Rantes. CCL5/Rantes, chemokine (C-C motif) ligand 5/Rantes; CXCL8/LL-8, blood-brain barrier; CXCL11/I-TAC, chemokine (C-X-C motif) ligand 11/I-TAC; MIE. major immediate early protein; SBCMV, primary HCMV isolate from a patient.

CCL5/Rantes, we observed increased mRNA expression for all three cytokines in SBCMV-infected pericytes (Figure 2C). RSAD2 $[29,30]$ was amplified as a control for genes specifically upregulated after HCMV infection (Figure 2B). Quantitative real-time PCR analysis indicated that CCL5/Rantes, CXCL11/I-TAC, CXCL8/IL-8 were upregulated after SBCMV infection by a factor of 3.2-fold, 3.2-fold and 44.7-fold, respectively, when normalized to transcription levels in mock-infected cells [31-33] (Figure 2D).

\section{Cellular upregulation of proinflammatory cytokines in SBCMV-infected brain pericytes}

After performing dual-labeled immunofluorescence for the HCMV MIE nuclear antigen (RITC-labeled) and the respective chemokine (FITC-labeled), we observed an increase in cellular expression of IL-8, CXCL11, and Rantes FITC, stained with donkey anti-goat antibodies (Figure 3A, B, C). IL-1 beta (25-fold) and IL-6 (8-fold) were also upregulated in SBCMV-infected pericytes by qRT-PCR when compared to mock-infected control cells
(Figure 4). We observed statistical significance for IL-1 beta and IL-6 but not TNF-alpha transcription.

\section{Pericytes are more permissive for SBCMV infection than} astrocytes and brain microvascular endothelial cells Cultured human cortical astrocytes, BMVEC and pericytes were stained positive for representative markers glial fibrillary acidic protein (GFAP), von Willebrand factor (vWF) and NG2 proteoglycan, respectively (Figure 5A). All three cell types were separately exposed to SBCMV for 72 hours (Figure 5B). Only pericytes cultures developed cytomegalic cytopathology compared to astrocytes and BMVEC (Figure 5B). Astrocytes and BMVEC cells exposed to SBCMV appeared no different than mock-infected cells, in that there was no evidence of infection by microscopy (Figure $5 \mathrm{~B}$ ). We then wanted to examine for evidence of viral lytic gene expression using qPCR. mRNA expression for the CMV late virion protein pp65 revealed that pericytes expressed pp65 mRNA at a very high level compared to controls, with no detection

Real-time RT-PCR Analysis for Proinflammatory Cytokines IL-1 $\beta$, IL- 6 and TNF $\alpha$, in Pericytes after SBCMV Infection

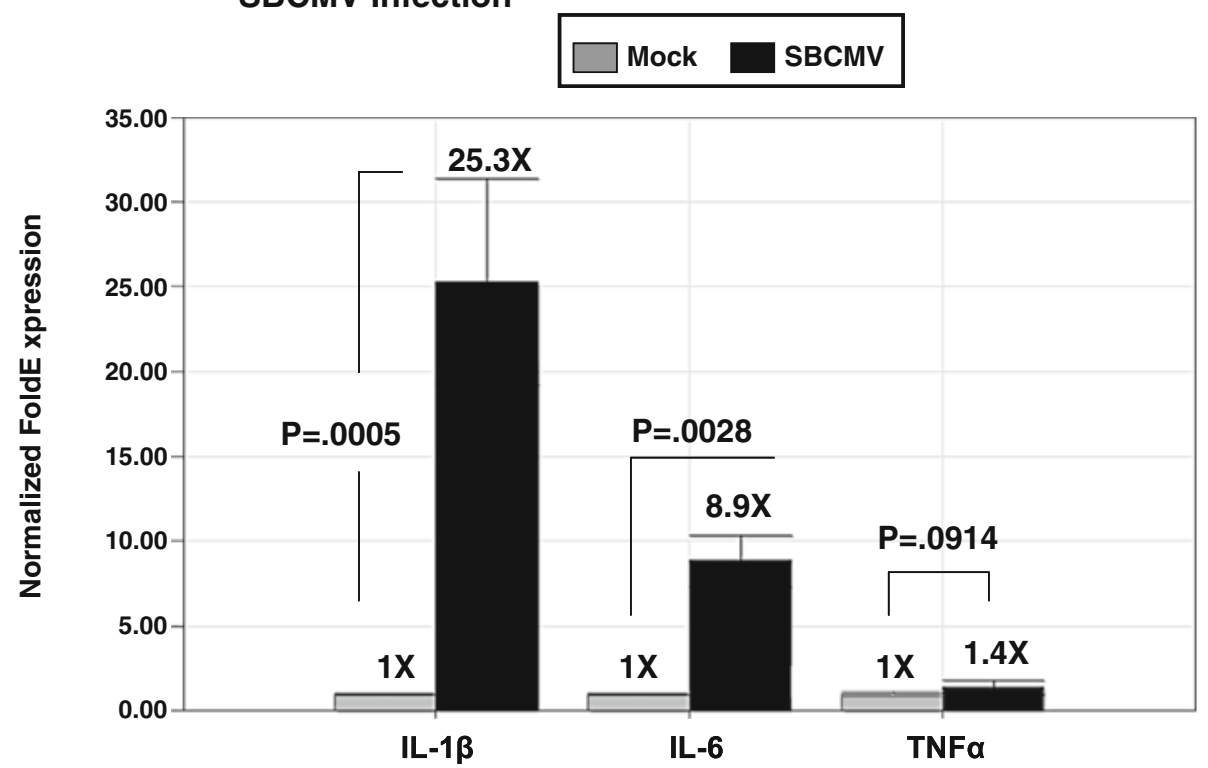

Figure 4 Real time RT-PCR analysis for proinflammatory cytokines. Cytokine IL-1 beta, IL-6 and TNF-alpha expression in pericytes 72 hours after SBCMV infection. This experiment was replicated three times, and amplifications were performed in triplicate and normalized to GAPDH. GAPDH, gyceralaldehyde phosphate dehydrogenase; RT-PCR, reverse transcription polymerase chain reaction; SBCMV, primary HCMV isolate from a patient. 
A.

Cellular Components of the TRI-CELL Culture Model of the Blood-Brain Barrier

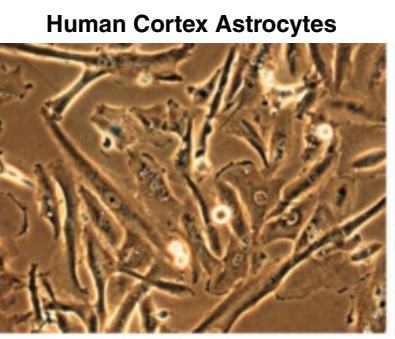
Human Cortex BMVEC
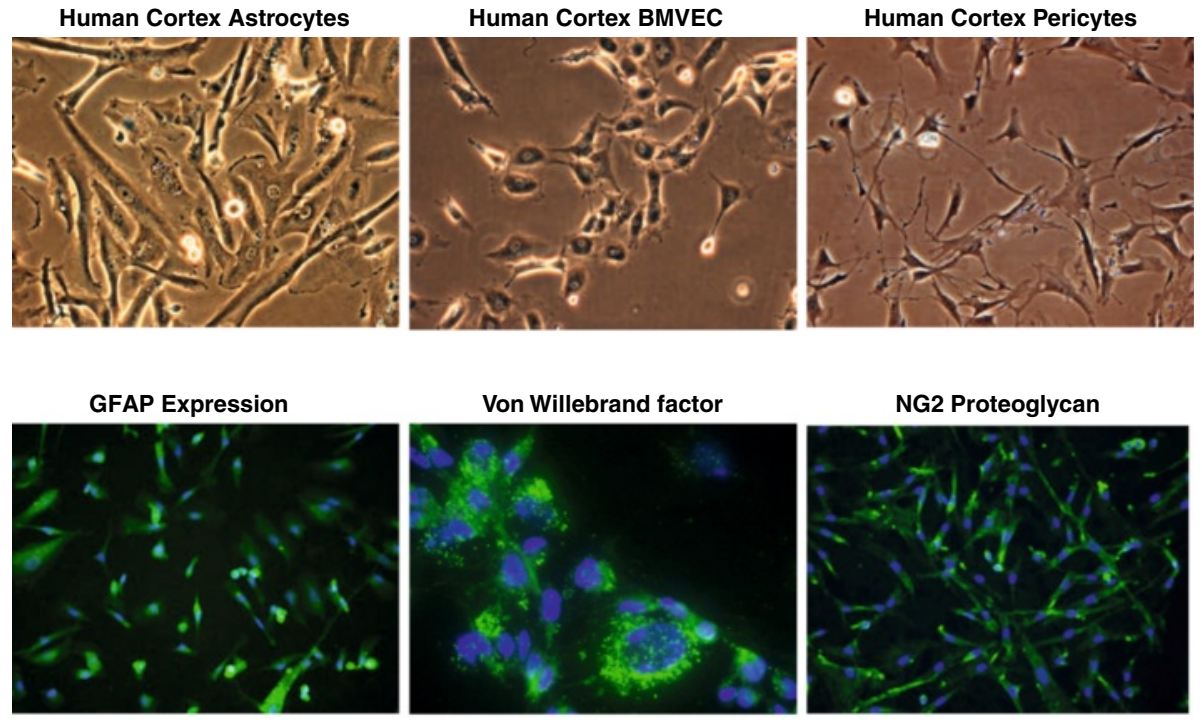

B.

\section{Mock Infected Control cells}

Blood-Brain Barrier Cells Infected with SBCMV
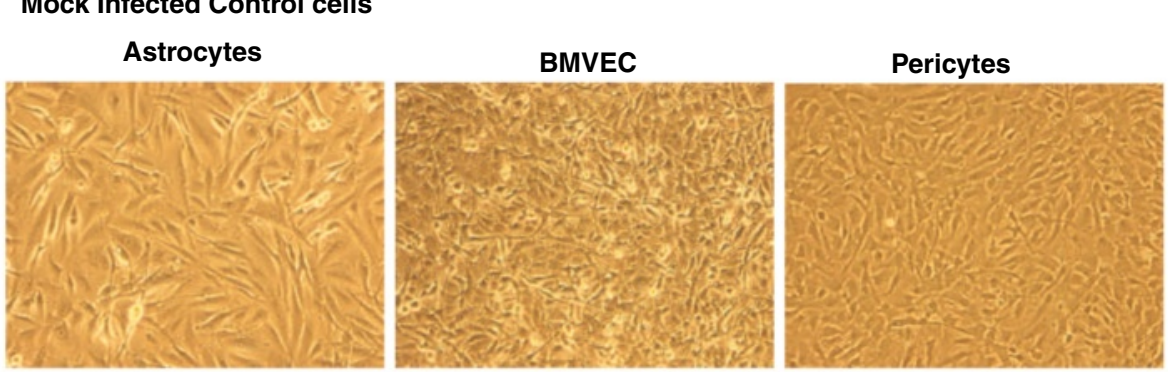

SBCMV infected 72 hours

Astrocytes

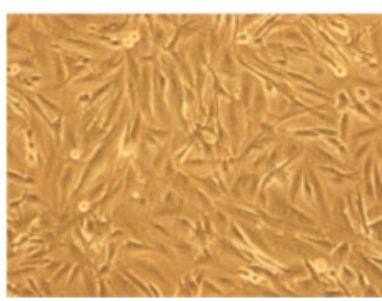

BMVEC

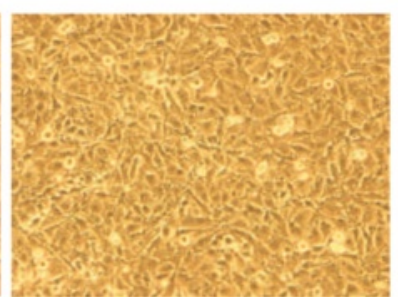

Pericytes

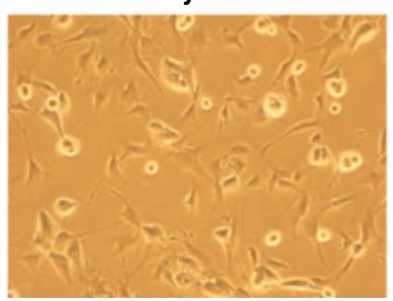

Figure 5 CMV infection of blood-brain barrier cellular components. Human brain cortical astrocytes, BMVEC and pericytes representing the major cellular components of the blood-brain barrier were infected with SBCMV. Cells cultivated to 50\% confluence were stained with representative markers. (A) Astrocytes were stained for glial fibillary acidic protein (GFAP), BMVEC for von Willebrand factor (vWF) and brain pericytes with NG2 proteoglycan antibodies. (B) All three cell types were infected with SBCMV for 72 hours. BMVEC, brain microvascular endothelial cells; GFAP, glial fibrillary acidic protein; NG2, neuron-glial antigen 2; SBCMV, primary HCMV isolate from a patient; vWF, von Willebrand factor.

above background expression for astrocytes and BMVEC cells (Figure 6). We then wanted to examine the expression of proinflammatory cytokines elicited by pericytes after SBCMV exposure. Utilizing a human cytokine ELISA assay with supernatants from SBCMV and heat-killed virus exposed pericytes 24 hours after exposure, we observed a marginal increase in TNF-alpha in pericytes exposed to both SBCMV and heat-killed virus (Figure 7A). 


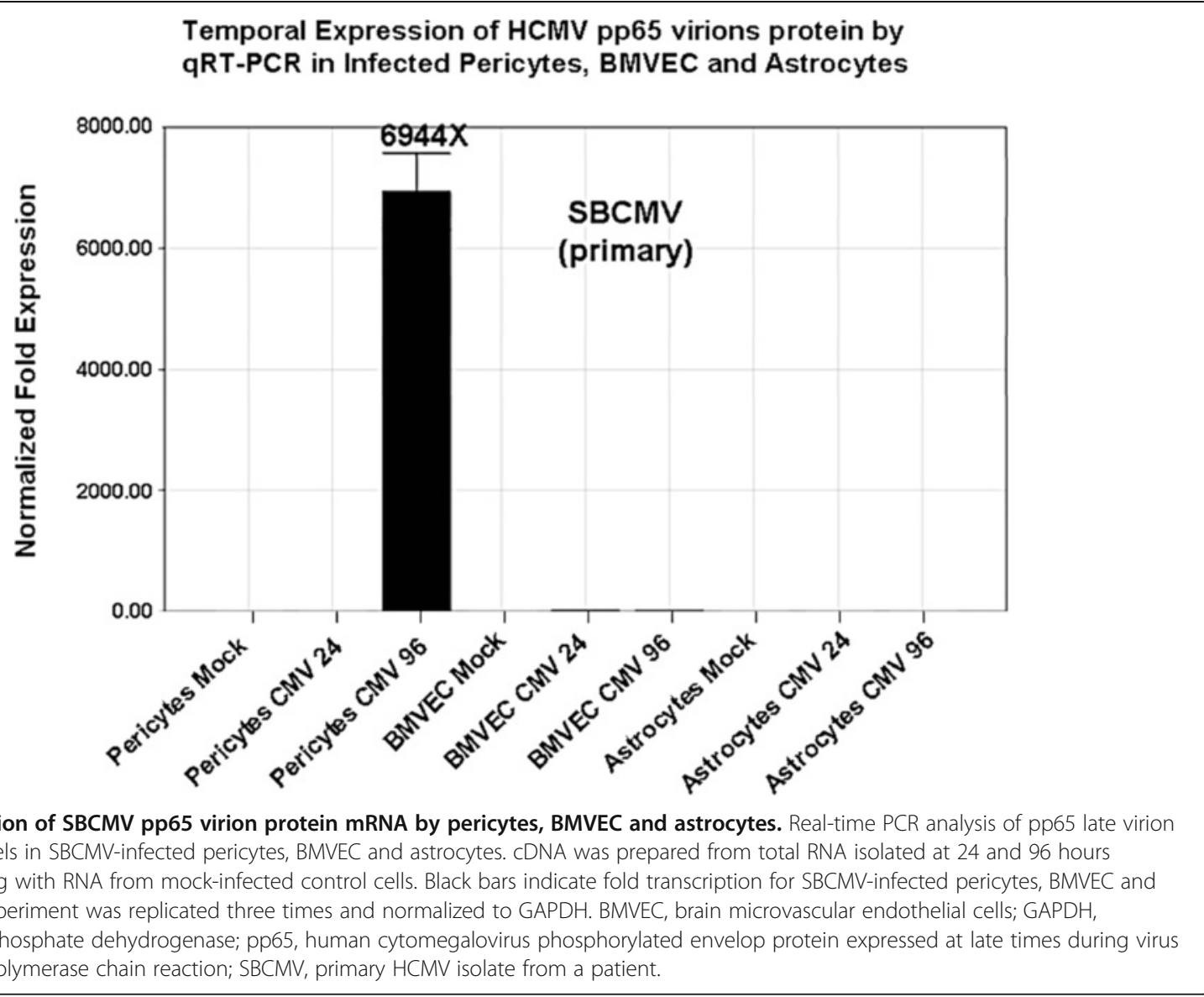

In addition, we also showed an increase in IL-6 in pericytes exposed to both SBCMV and heat-killed virus, although a higher level of IL-6 was observed in those pericytes exposed to untreated SBCMV compared to heatkilled virus. No significant change in TGF-beta levels was observed in 24-hour virus-exposed pericytes when compared to uninfected control cells (Figure 7A). Analysis of TNF-alpha and IL-6 secreted from pericytes in infected cell supernatants showed no induction of TNF-alpha compared to mock-infected controls (Figure 7B) and a 6.6-fold increase in IL-6 protein levels was observed in SBCMV-infected cell supernatants when compared to controls levels (Figure 7C).

\section{Cytomegalovirus infects pericytes in vivo}

Single and dual IHC staining was performed on archival brain tissue from an HIV-infected patient with HCMVdisseminated $\mathrm{CNS}$ disease. We demonstrated the presence of HIV by single label IHC (Figure 8A, B) using HIV group-specific antigen (Gag) antibodies, and for HCMV in (Figure 8C, D) using virus major immediate early gene (MIE) antibodies. To demonstrate CMV infection of pericytes in archival brain tissue, we performed dual-labeled IHC using antibodies for both NG2 proteoglycan, a cytoplasmic marker for pericytes [27, 28], and for HCMV MIE, a nuclear marker to detect CMVinfected pericytes. We demonstrated dual cytoplasmic (NG2 proteoglycan, brown) and nuclear staining (HCMV MIE, red) in CMV-infected archival brain tissue. These results support our in vitro proof of concept data indicating that human brain vascular pericytes support CMV infection.

\section{Discussion}

The role of brain vascular pericytes regarding CMV infectivity and virus dissemination into the CNS is unknown. The role of pericytes in HCMV-induced neuroinflammation is also unknown. Determining the mechanisms involved in the dissemination of CMV in the CNS is critical for understanding how CMV infection in utero may cause neurodevelopmental abnormalities in children $[34,35]$. In this study, we found that pericytes are highly permissive for HCMV lytic replication using a lowpassaged clinical isolate of human CMV (SBCMV). We observed typical CMV cytopathology and staining patterns for MIE 1, 2 and the late viral protein pp65 as well as virion production consistent with lytic replication in permissive cells [4]. 
A.
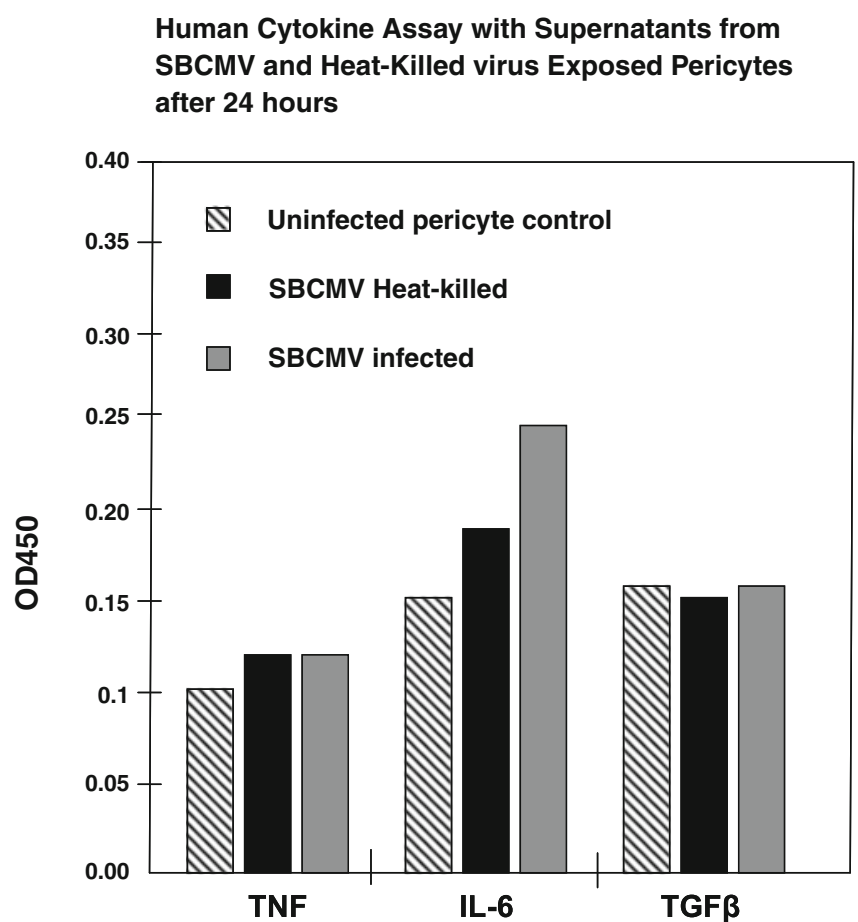

B.

TNF- $\alpha$ Expression in SBCMV infected Pericytes after 24 hours exposure

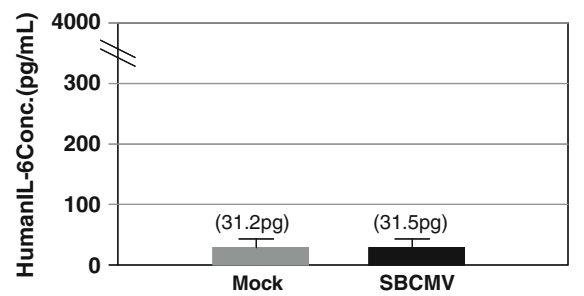

C.

IL-6 Expression in SBCMV Infected Pericytes after 24 hours exposure

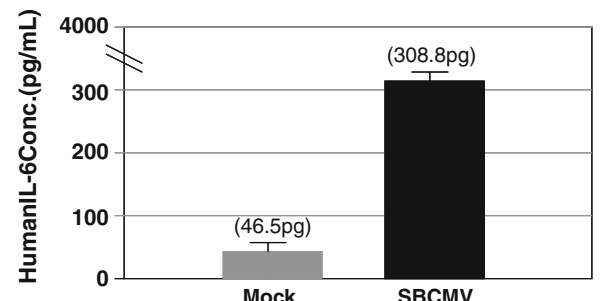

Figure 7 Human cytokine ELISA assay. Analysis of human cytokines after SBCMV infection of brain vascular pericytes. A human cytokine ELISA assay was performed on supernatants from SBCMV-infected pericytes, SBCMV heat-killed pericytes and mock-infected cells. Shown are the relative amounts of TNF-alpha, IL-6 and TGF-beta in cell culture supernatants elicited 24 hours postexposure (A). Quantitative measurements IL-6 and TNF-alpha secreted from pericytes in infected cell supernatants 24 hours postinfection was based on optical density utilizing a standard curve for human IL-6 (B) and human TNF-alpha (C). Analysis was performed in triplicate and values were expressed in picograms/milliliter. IL, interleukin; SBCMV, primary HCMV isolate from a patient; TGF-beta, tumor growth factor-beta; TNF-alpha, tumor necrosis factor-alpha.

We felt that it was essential to use a low-passaged clinical isolate of HCMV in these studies because laboratoryadapted strains of HCMV are passaged in culture and accumulate deletions as well as genome rearrangements for growth adaptation in fibroblasts, which are routinely used to cultivate CMV in the laboratory [36-38]. Therefore, when we observed a lower level of viral replication kinetics in pericytes for the SBCMV isolate compared to the Towne lab CMV strain, we attributed this finding to the lack of adaptation of a virus that was only passaged in culture twice after initial isolation (Figure 2B). Studies by Cha et al. in 1996 [36] showed that human CMV clinical isolates carry up to 19 genes not found in the highly passaged laboratory strains of HCMV. These genome differences may account for the differences in virulence and tissue tropism $[39,40]$.

The loss of HCMV UL128-to-UL150 loci, and specifically the UL128, UL130 and UL131 gene cluster observed in the laboratory-adapted strains of HCMV like AD169 and Towne that are important for virus infection and spread in epithelial and endothelial cells, due to extensive passage in fibroblasts, appears not to be required for infection and virus spread in pericytes infected with HCMV Towne [41]. 


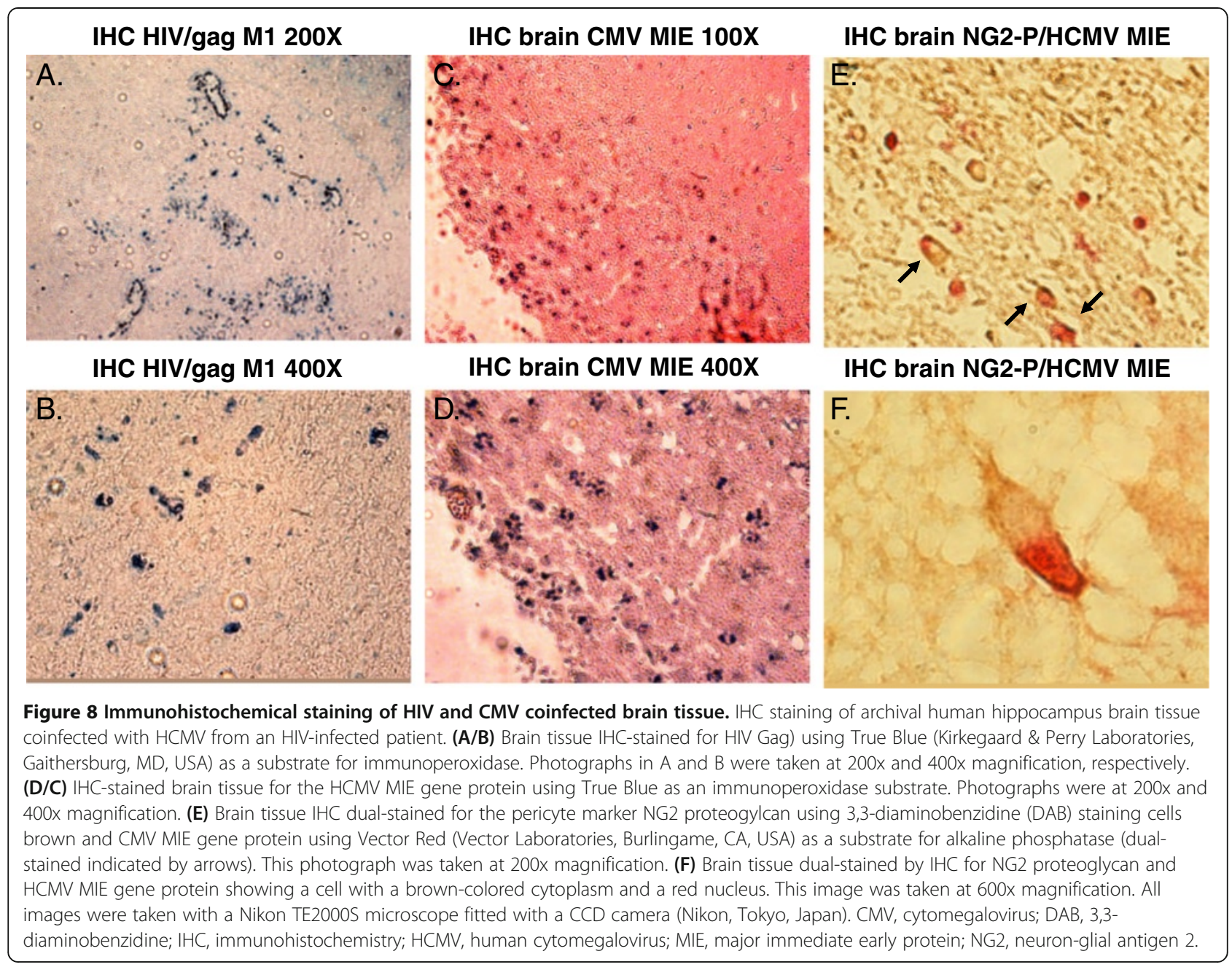

A comparative analysis of SBCMV infectivity in vitro with other cellular components of the BBB (astrocytes and BMVEC) suggests that pericytes are the most permissive of this group for CMV lytic replication. Thus they may serve as a viral CNS amplification reservoir that could greatly enhance CMV dissemination into the brain. In addition, a proinflammatory cytokine cascade was expressed by brain pericytes following SBCMV infection for 72 hours. This included upregulation of chemotactic cytokines CCL5/Rantes, I-TAC/CXCL11, and IL-8/ CXCL8, as well as IL1-beta and IL-6 with no induction of TNF-alpha (Figure 4) which correlates with our semiquantitative ELISA assay (Figure 7A). These cytokines are mainly chemotactic for neutrophils, $\mathrm{T}$ cells, basophils and eosinophils and would serve to contribute to neuroinflammation at the blood-brain barrier (Table 1).

Studies that demonstrate CMV infection of astrocytes report the production of chemokines, mainly CCL2 and cytokine transforming growth factor beta (TGF-beta) $[42,43]$. In these studies, none of the proinflammatory cytokines used (TNF-alpha, IL-1beta, and IL-6) were found to be induced in astrocytes in a mouse model system using murine cytomegalovirus (MCMV) [42]. Using a low-passaged clinical isolate of HCMV (SBCMV) to infect a commercial source of primary human astrocytes at a low multiplicity of infection, we found no clear evidence of CMV infection in these cells after 72 hours in culture and by qPCR amplification (Figures 6 and 7).

There are in vitro reports (using laboratory-adapted strains of CMV in human, murine and nonhuman primate model systems) that CMV infects both BMVEC and astrocytes [42-45]. However our study, using a low multiplicity of infection with a primary clinical HCMV isolate obtained from a child with disseminated CMV disease, found no evidence of CMV pp65 message above background in infected BMVEC or astrocytes for up to 96 hours after infection when compared to pericytes (Figure 6). The Towne strain of HCMV has been highly passaged in culture and has accumulated multiple mutations and deletion and is expected to have broader tropism when compared to a low-passaged primary clinical CMV isolate. The HCMV infections we performed were 
Table 1 Microarray results three days after SBCMV infection of brain vascular pericytes representing the highest fold change in transcription linked to neuroinflammation.

\begin{tabular}{|c|c|c|}
\hline $\begin{array}{l}\text { Genes } \\
\text { upregulated }\end{array}$ & $\begin{array}{l}\text { Fold } \\
\text { change }\end{array}$ & Some associated functions \\
\hline RSAD2 & 390 & Protein directly induced by cytomegalovirus \\
\hline ISG20 & 380 & Interferon-stimulated exonuclease \\
\hline CCL5 & 364 & $\begin{array}{l}\text { Chemotactic cytokine for activated T cells, } \\
\text { eosinophils and basophils }\end{array}$ \\
\hline CXCL11 & 337 & Chemotactic cytokine for activated T cells \\
\hline$\overline{\mathrm{CCL} 5}$ & 141 & $\begin{array}{l}\text { Chemotactic cytokine for activated T cells, } \\
\text { eosinophils and basophils }\end{array}$ \\
\hline IFI27 & 117 & $\begin{array}{l}\text { Interferon alpha inducible gene/ } \\
\text { inflammation }\end{array}$ \\
\hline TAC1 & 111 & $\begin{array}{l}\text { Neurotransmitter, induction of behavioral } \\
\text { responses }\end{array}$ \\
\hline CCL20 & 76 & $\begin{array}{l}\text { Chemotactic cytokine for lymphocytes and } \\
\text { neutrophils }\end{array}$ \\
\hline HERC5 & 60 & $\begin{array}{l}\text { Interferon-induced ubiquitin-E3 protein } \\
\text { ligase }\end{array}$ \\
\hline IL8 & 4 & Chemotactic cytokine for neutrophils \\
\hline \multicolumn{3}{|c|}{$\begin{array}{l}\text { CCL5, C chemokine (C-C motif) ligand 5; CCL20, chemokine (C-C motif) ligand } \\
\text { 20; CXCL11, chemokine (C-X-C motif) ligand 11; HERC5, probable E3 } \\
\text { ubiquitin-protein ligase HERC5; IFI27, interferon alpha-inducible protein 2; IL8, } \\
\text { interleukin 8; ISG20, interferon-stimulated gene } 20 \mathrm{kDa} \text { protein; RSAD2, radical } \\
\text { S-adenosyl methionine domain-containing protein 2; TAC1, tachykinin } \\
\text { precursor 1. }\end{array}$} \\
\hline
\end{tabular}

at a low MOI and we monitored cytopathic effects after 72 hours in Figure 5 and, using mRNA from the same cultures, we looked for pp65 late transcripts at 24 and 96 hours postinfection, which allows time for productive infection (late gene expression). The infection was performed at low MOI using a primary HCMV isolate, a 24- and 96-hour time point postinfection, and amplification of the late protein pp65 transcripts likely contributed to the low level of productive infection seen in astrocytes. We observe that longer time periods postinfection, a higher MOI, and the use of a laboratory-adapted strain of virus will produce higher levels of productive infection in fibroblasts and pericytes. Even more, we observed that SBCMV-infected pericytes elicited higher levels of IL-6 when compared to mock-infected or heat-killed SBCMV controls. Marginal increases in TNF-alpha levels were observed in pericyte cultures exposed to both SBCMV and heat-killed virus for 24 hours (Figure 7A), while no change was observed in TGF-beta levels in virus-exposed cells compared to uninfected control cells over this time period. Increased levels of IL-6 and no induction of TNFalpha were observed in SBCMV-infected pericyte supernatants at 24 hours postinfection. As we were not able to obtain archival brain tissue from newborns that were only CMV infected, we utilized CMV-infected brain tissue from a patient coinfected with HIV. Because CMV is a latent opportunistic pathogen that undergoes reactivation

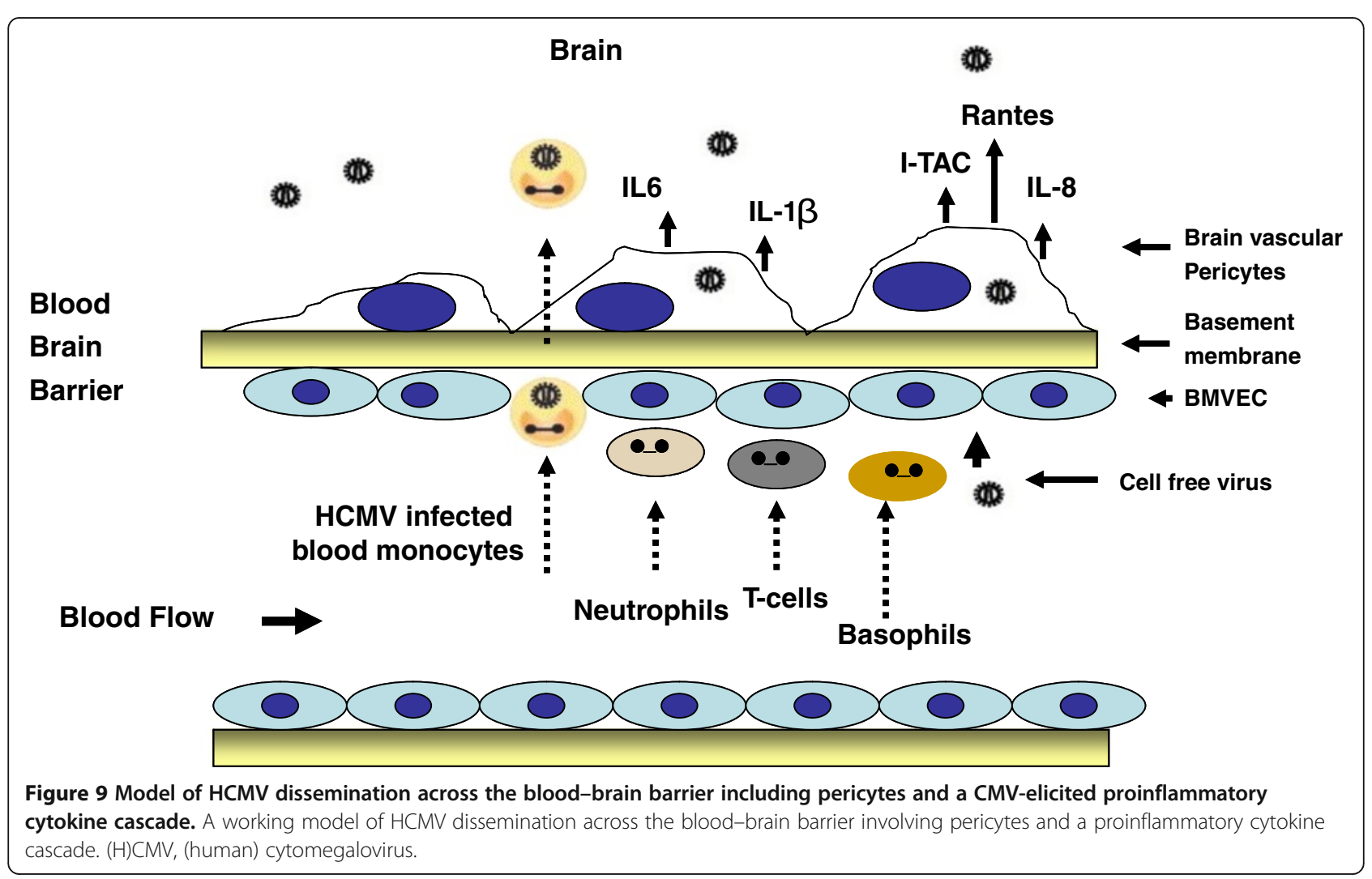


from latency in individuals that are immune-compromised, HIV-infected patients can develop CMV neuropathology [46-49]. Using HIV-CMV-infected archival human brain tissue, we demonstrated CMV infection of brain pericytes using dual-labeled IHC. We observed both HIV-positive cells in this hippocampal tissue as well as CMV cytomegalic cells with a characteristic CMV MIE nuclear staining pattern. In addition, we demonstrated brain cells staining positive for the pericyte marker NG2 proteoglycan, which co-stained for HCMV MIE gene protein, suggesting that pericytes support CMV infection in vivo (Figure 8). We realize that no specific pericyte marker has been identified. The use of alpha smooth muscle actin (alpha-SMA) has been employed by investigators to identify pericytes in situ, however in the brain, only pericytes located near arterioles routinely stain positive for alpha-SMA. In primary cultures, only $5 \%$ of newly isolated capillary pericytes stain positive for this marker [22]. Studies by Ozerdem et al. [28] suggested that NG2 proteogylcan is expressed exclusively by pericytes (mural cells) during vascular morphogenesis. With this reasoning we used NG2 proteogylcan as a marker for pericytes in our IHC experiments.

\section{Conclusion}

Based in part on these findings, we proposed a model of HCMV dissemination from the blood across the BBB into the brain (Figure 9). As HCMV traffics into the brain, the virus encounters brain microvascular endothelial cells that may be marginally permissive for infection [50,51]. HCMV-infected blood monocytes may also gain access to the brain via chemotactic factors like monocyte chemotactic protein 1 (MCP-1) [52]. Cell-free virus could also gain access to the brain via pinocytosis or paracellular transport between brain microvascular endothelial cells (Figure 9). All routes require HCMV to interact with pericytes. Therefore we propose that brain vascular pericytes serve as a virus amplification reservoir at the BBB interface and, upon infection, they express a proinflammatory cytokine cascade that could result in increased inflammation and contribute to CMV neuropathology. HCMV upregulation of proinflammatory cytokines IL-1beta, IL-6 and TNF-alpha in permissive cell has been extensively studied. At early times postinfection, several studies have shown HCMV activation of IL-1, TNF-alpha, nuclear factor-kappa B (NF-kB) and various mitogen activated protein kinases (MAPKs) [53-57]. A second phase of activation occurs after virus entry, induced partly by the major viral transcriptional activators IE1 and IE2, which are thought to be required for initial virus replication. Stimulation of IL-1 and TNF-alpha pathways may also support viral dissemination via recruitment of permissive cells, as a result of increased chemokine secretion such as IL-8, IL-6, and Rantes [58-61]. More recent studies are beginning to suggest the ability of HCMV to suppress IL-1 and TNF-alpha signaling pathways at different times after infection $[62,63]$. However, the exact mechanisms involved in HCMV regulation of proinflammatory signaling pathways will require further investigation. Taken together, these studies suggest that as HCMV traffics the neurovasculature, virus infection of pericytes is imminent, resulting in infection amplification and the induction of cytokines that heightens the inflammatory state of the CNS microenvironment.

The model in Figure 9 indicates how HCMV might interact with pericytes leading to several potential responses. Infected blood monocytes could either extravasate between BMVEC and transmit infection to pericytes via cell-to-cell contact, or cell-free virus could pass between BMVEC via paracellular transport, to directly infect pericytes. In support of this model, we find pericytes to be fully permissive for HCMV infection. We also suggest that pericytes directly serve as amplification sites for productive viral infection, which would allow CMV to disseminate further into the brain parenchyma.

CMV infection of pericytes would result in a cytokine cascade that would serve to attract inflammatory cells such as neutrophils, basophils and $\mathrm{T}$ cells that would in aggregate contribute to neuroinflammation. Figure 9 represents a summary of our findings and exemplifies a model of our hypothesis with regard to HCMV interaction with cellular components of the blood-brain barrier. We are aware that a congenital infection occurs during prenatal life when the blood-brain barrier is still very immature and leaky, allowing more access of HCMV to the brain. Still these data are provocative and require investigators to take a closer look at the role of pericytes in this process.

\section{Abbreviations}

Alpha-SMA: alpha smooth muscle actin; interleukin-8: CXCL8/L8; BBB: bloodbrain barrier; BCA: bicinchoninic acid; BMVEC: brain microvascular endothelial cells; CCD: charge-coupled device camera; CCL5/Rantes: chemokine (C-C motif) ligand 5/Rantes; CCL20: chemokine (C-C motif) ligand 20; CDNA: DNA copy of mRNA after reverse transcription; CMV: cytomegalovirus; CNS: central nervous system; CXCL11/I-TAC: chemokine (C-X-C motif) ligand 11/I-TAC; DAB: 3,3-diaminobenzidine; DAPI: 4',6-diamidino-2-phenylindole;

EDTA: ethylenediaminetetraacetic acid; ELISA: enzyme-linked immunosorbent assay; EM: electron microscopy; FITC: fluorescein isothiocyanate;

GAPDH: gyceralaldehyde phosphate dehydrogenase; GFAP: glial fibrillary acidic protein; HCMV: human cytomegalovirus; HERC5: probable E3 ubiquitinprotein ligase HERC5; IgG: immumoglobulin G; IFI27: interferon alphainducible protein 27; IHC: immunohistochemistry; IL: interleukin;

ISG20: interferon-stimulated gene $20 \mathrm{kDa}$ protein; mAb810: monoclonal antibody to human cytomegalovirus major immediate early proteins 1 and 2: MAPKs: mitogen activated protein kinases; MCMV: murine cytomegalovirus; MCP-1: monocyte chemotactic protein-1; MIE 1 and 2: human cytomegalovirus major immediate early gene/proteins 1 and 2; MOI: multiplicity of infection; mRNA: messenger ribonucleic acid; NFkB: nuclear factor-kappa B; NG2: neuron-glial antigen 2; PAGE: polyacrylamide gel electrophoresis; pp65: human cytomegalovirus phosphorylated envelop protein expressed at late times during virus replication; qRT-PCR: quantitative reverse transcription polymerase chain reaction; RITC: rhodamine B isothiocyanate; RSAD2: radical S-adenosyl methionine domain-containing protein 2; RT-PCR: reverse transcription polymerase chain reaction; SBCMV: primary HCMV isolate from a patient; SDS: sodium dodecyl sulfate; TAC1: tachykinin precursor 1; TEM: Transmission electron microscopy; 
TGF-beta: tumor growth factor-beta; TJ: tight junction; TNF-alpha: tumor necrosis factor-alpha; vWF: von Willebrand factor.

\section{Competing interests}

The authors declare that they have no competing interests.

\section{Acknowledgements}

We thank Dr. Ravit Arav-Boger from Johns Hopkins University for the SBCMV isolate and Dr. Milan Fiala from UCLA for the BMVEC cells. We thank Drs. James E.K. Hildreth and Diana Marver for advice in the preparation of this manuscript. We thank Margit Lusckay and Audese Green for their technical advice. TEM was performed in part at the Vanderbilt University Medical Center electron microscopy resource facility (National Institutes of Health (NIH) grant numbers DK20539 and DK58404). DJA was supported by pilot grants from Meharry Clinical and Translational Research Center (MeTRC, NIH grant number U54RR026140), the Vanderbilt Meharry Center for AIDS Research (CFAR) (NIH grant number P30AI054999), the Meharry Medical College Center for Clinical Research (NIH grant number P20RR011792), and the BlueCross BlueShield of Tennessee Health Foundation.

\section{Authors' contributions}

DJA conceived and designed the study. DJA, AMC, SMK, WQZ, and HEV performed the experiments. DJA drafted the manuscript. All authors have read and approved the final version of the manuscript.

Received: 13 November 2011 Accepted: 24 April 2012

Published: 18 May 2012

\section{References}

1. Boppana SB, Fowler KB, Pass RF, Rivera LB, Bradford RD, Lakeman FD, Britt WJ: Congenital cytomegalovirus infection: association between virus burden in infancy and hearing loss. J Pediatr 2005, 146:817-823.

2. Colugnati FA, Staras SA, Dollard SC, Cannon MJ: Incidence of cytomegalovirus infection among the general population and pregnant women in the United States. BMC Infect Dis 2007, 7:71.

3. Sessions CF, Taeusch HW: In Viral infections of the newborn. In Diseases of the newborn. Edited by Taeusch HW, Ballard RA, Avery ME. Philadelphia: W. B. Saunders; 1991:331-349.

4. Stagno S, Pass RF, Dworsky ME, Henderson RE, Moore EG, Walton PD, Alford CA: Congenital cytomegalovirus infection: the relative importance of primary and recurrent maternal infection. N Engl J Med 1982, 306:945-949.

5. Demmler GJ: Congenital cytomegalovirus infection and disease. Adv Pediatr Infect Dis 1996, 11:135-162.

6. Kylat Rl, Kelly EN, Ford-Jones EL: Clinical findings and adverse outcome in neonates with symptomatic congenital cytomegalovirus (SCCMV) infection. Eur J Pediatr 2006, 165:773-778.

7. Cheeran CJ, Lokensgard JR, Schleiss MR: Neuropathogenesis of congenital cytomegalovirus infection: disease mechanisms and prospects for intervention. Clin Microbiol Rev 2009, 22:99-126.

8. Fowler K, McCollister FP, Dahle AJ, Boppana S, Britt WJ, Pass RF: Progressive and fluctuating sensorineural hearing loss in children with asymptomatic congenital cytomegalovirus infection. J Pediatr 1997, 130:624-630.

9. Pass RF, Fowler KB, Boppana SB, Britt WJ, Stagno S: Congenital cytomegalovirus infection following first trimester maternal infection: symptoms at birth and outcome. J Clin Virol 2006, 35:216-220.

10. Tang HJ, Lui YC, Yen MY, Chen YS, Wann SR, Lin HH, Lee SS, Lin WR, Huang CK, Su BA, Chang PC, Li CM, Tseng HH: Opportunistic infections in adults with acquired immunodeficiency syndrome: a comparison of clinical and autopsy findings. J Microbiol Immunol Infect 2006, 4:310-315.

11. Arribas JR, Clifford DB, Fichtenbaum CJ, Commins DL, Powderly WG, Storch $\mathrm{GA}$ : Level of cytomegalovirus (CMV) DNA in cerebrospinal fluid of subjects with AIDS and CMV infection of the central nervous system. $J$ Infect Dis 1996, 2:527-531.

12. Arribas JR, Storch GA, Clifford DB, Tselis AC: Cytomegalovirus encephalitis. Ann Intern Med 1996, 125:577-587.

13. Whitley RJ: Herpes simplex virus infections of the central nervous system. Encephalitis and neonatal herpes. Drugs 1991, 42:406-427.

14. Balladh P, Braun A, Nedergaard M: The blood-brain barrier: an overview, structure, regulation and clinical implications. NeuroBio Dis 2004, 16:1-13.
15. Englehardt B: Development of the blood-brain barrier. Cell Tissue Res 2002, 314:119-129.

16. Garberg P, Ball M, Borg N, Cecchelli R, Fenart L, Hurst RD, Lindmark T, Mabondzo A, Nilsson JE, Raub TJ, Stanimirovic D, Terasaki T, Oberg JO: In vitro models for the blood-brain barrier. Toxicol In Vitro 2005, 19:299-334.

17. Ramsauer M, Krause D, Dermietzel R: Angiogenesis of the blood-brain barrier in vitro and the function of cerebral pericytes. FASEB J 2002, 16:1274-1276.

18. Shepro D: Morel NM: Pericyte physiology. FASEB J 1993, 7:1031-1038.

19. Tsukita S, Furuse M, Itoh M: Multifunctional strands in tight junctions. Nat Rev Mol Cell Biol 2001, 2:285-293.

20. Balabanov R, Dore-Duffy P: Role of CNS microvascular pericytes in the blood brain barrier. J Neurosci Res 1998, 53:637-644.

21. Dore-Duffy P: Pericytes: pluripotent cells of the blood brain barrier. Curr Pharm Des 2008, 16:1581-1593.

22. Dore-Duffy P, Cleary K: Morphology and properties of pericytes. Methods Mol Biol 2011, 686:49-68.

23. Lai $\mathrm{CH}$, Kuo KH: The critical component to establish in vitro BBB model: pericyte. Brain Res Rev 2005, 50:258-265.

24. Price P, Eddy KS, Papadimitriou JM, Robertson TA, Shellam GR: Cytomegalovirus infection of adipose tissue induces steatitis in adult mice. Int J Exp Pathol 1990, 4:557-571.

25. Fiala M, Singer EJ, Commins D, Mirzapoiazova T, Verin A, Espinosa A, Ugen K, Bernas M, Witte M, Weinand M, Lossinsky AS: HIV-1 antigens in neurons of cocaine-abusing patients. Virol J 2008, 2:24-31.

26. Bryant P, Morley C, Garland S, Curtis N: Cytomegalovirus transmission from breast milk premature babies: does it matter? Arch Dis Child Feta Neonatal Ed 2002, 87:F75-F77.

27. Alcendor DJ, Knobel S: Identifying dysregulated genes induced by Kaposi's sarcoma-associated herpesvirus (KSHV). J Vis Exp Sep 2010, 14:43. pii: 2078, doi: 10.3791/2078.

28. Ozerdem U, Grako KA, Dahlin-Huppe K, Monosov E, Stallcup WB: NG2 proteogylcan is expressed exclusively by mural cells during vascular morphogenesis. Dev Dyn 2001, 222:218-227.

29. Chin KC, Cresswell P: Viperin (CIG5), an IFN-inducible antiviral protein directly induced by cytomegalovirus. Proc Natl Acad Sci USA 2001, 98:15125-15130.

30. Olofsson PS, Jatta K, Wagsate D, Gredmark S, Hedin U, Paulsson-Berne G, Söderberg-Nauclér C, Hansson GK, Sirsjö A: The antiviral cytomegalovirusinducible gene 5/viperin is expressed in atherosclerosis and regulated by proinflammatory agents. Arterioscler Thromb Vasc Biol 2005, 25:e113-e116.

31. Billstrom Schroeder M, Worthen GS: Viral regulation of Rantes expression during human cytomegalovirus infection of endothelial cells. J Virol 2001, 7:3383-3390.

32. Caposio P, Musso T, Luganini A, Inoue H, Gariglio M, Landolfo S, Gridaudo G: Targeting the NF-kappaB pathway through pharmacological inhibition of IKK2 prevents human cytomegalovirus replication and virus-induced inflammatory response in infected endothelial cells. Antiviral Res 2006, 3:175-184.

33. Cinati J Jr, Kotchetkov R, Weimer E, Blaheta RA, Scholz M, Vogel JU, Gumbel HO, Doerr HW: The antisense oligonucleotide ISIS 2922 prevents cytomegalovirus-induced upregulation of IL- 8 and ICAM- 1 in cultured human fibroblasts. J Med Virol 2000, 3:313-323.

34. Alford CA, Britt WJ: In Cytomegalovirus, The Human Herpesviruses. Edited by Roizman B, Whitley RJ, Lopez C. New York: Raven; 1993:227-255.

35. Boppana SB, Fowler KB, Vaid Y, Hedlund G, Stagno S, Britt WJ, Pass RF: Neuroradiographic findings in the newborn period and long-term outcome in children with symptomatic congenital cytomegalovirus infection. Pediatrics 1997, 9:409-414.

36. Cha TA, Tom E, Kemble GW, Duke GM, Mocarski ES, Spaete RR: Human cytomegalovirus clinical isolates carry at least 19 genes not found in laboratory strains. J Virol 1996, 1:78-83.

37. MacCormac LP, Grundy JE: Two clinical isolates and the Toledo strain of cytomegalovirus contain endothelial cell tropic variants that are not present in the AD169, Towne, or Davis strains. J Med Virol 1999, 57:298-307.

38. Murphy E, Yu D, Grimwood J, Schmutz J, Dickson M, Jarvis MA, Hahn G, Nelson JA, Myers RM, Shenk TE: Coding potential of laboratory and clinical strains of human cytomegalovirus. Proc Natl Acad Sci USA 2003, 25:14976-14981. 
39. Plachter B, Sinzger C, Jahn G: Cell types involved in replication and distribution of human cytomegalovirus. Adv Virus Res 1996, 46:195-261.

40. Sinzger C, Schmidt K, Knapp J, Kahl M, Beck R, Waldman J, Hebart H, Einsele $H$, Jahn G: Modification of human cytomegalovirus tropism through propagation in vitro is associated with changes in the viral genome. J Gen Virol 1999, 80:2867-2877.

41. Ryckman BJ, Jarvis MA, Drummond DD, Nelson JA, Johnson DC: Human cytomegalovirus entry into epithelial and endothelial cells depends on genes UL128 to UL150 and occurs by endocytosis and low-pH fusion. J Virol 2006, 80:710-722

42. Cheeran MC, Hu S, Yager SL, Gekker G, Peterson PK, Lokensgard JR: Cytomegalovirus induces cytokines and chemokines production differentially in microglia and astrocytes: antiviral implications. J Neurovirol 2003, 7:135-147.

43. Kossmann T, Morganti-Kossmann Orenstein JM, Britt WJ, Wahl SM, Smith PD: Cytomegalovirus production by infected astrocytes correlates with transforming growth factor-beta release. J Infect Dis 2003, 187:534-541.

44. Lokensgard JR, Cheeran MC, Gekker G, Hu S, Chao CC, Peterson PK: Human cytomegalovirus replication and modulation of apoptosis in astrocytes. J Hum Virol 1999, 2:91-101.

45. Carlson JR, Chang WL, Zhou SS, Tarantal AF, Barry PA: Rhesus brain microvascular endothelial cells are permissive for rhesus cytomegalovirus infection. J Gen Virol 2005, 3:545-549.

46. Anderson AM, Fountain JA, Green SB, Bloom SA, Palmore MP: Human immunodeficiency virus-associated cytomegalovirus infection with multiple small vessel cerebral infarcts in the setting of early immune reconstitution. J Neurovirol 2010, 2:179-184.

47. Jellinger KA, Setinek U, Drlicek M, Bohm G, Steurer A, Lintner F: Neuropathology and general autopsy findings in AIDS during the last 15 years. Acta Neuropathol 2000, 2:213-220.

48. Myerson D, Hackman RC, Nelson JA, Ward DC, McDougall JK: Widespread presence of histologically occult cytomegalovirus. Hum Pathol 1984 15:430-439.

49. Miller RF, Howard MR, Frith P, Perrons CJ, Pecorella I, Lucas SB: Herpesvirus infection of the eye and brain in HIV infected patients. Sex Transm Infect 2000, 4:282-286

50. Jarvis M, Nelson JA: Human cytomegalovirus persistence and latency in endothelial cells and macrophages. Curr Opin Microbiol 2002, 5:403-407.

51. Lathey JL, Wiley CA, Verity MA, Nelson JA: Cultured human brain capillary endothelial cells are permissive for infection by human cytomegalovirus. Virology 1990, 1:266-273

52. Stern JL, Slobedman B: Human cytomegalovirus latent infection of myeloid cells directs monocyte migration by up-regulating monocyte chemotactic protein-1. J Immunol 2008, 10:6577-6585.

53. Yurochko AD, Huang ES: Human cytomegalovirus binding to human monocytes induces immunoregulatory gene expression. J Immunol 1999, 162:4806-4816.

54. Kowalik TF, Wing B, Haskill JS, Azizkhan JC, Baldwin AS Jr, Huang ES: Multiple mechanisms are implicated in the regulation of NF-kappa B activity during human cytomegalovirus infection. Proc Natl Acad Sci USA 1993, 90:1107-1111.

55. Yurochko AD, Hwang ES, Rasmussen L, Keay S, Pereira L, Huang ES: The human cytomegalovirus UL55 (gB) and UL75 (gH) glycoprotein ligands initiate the rapid activation of Sp1 and NF-KB during infection. J Virol 1997, 71:5051-5059.

56. Yurochko AD, Mayo MW, Poma EE, Baldwin AS Jr, Huang ES: Induction of the transcription factor Sp1 during human cytomegalovirus infection mediates upregulation of the p65 and p105/p50 NF-kB promoters. J Virol 1997, 71:4638-4648.

57. Johnson RA, Huong SM, Huang ES: Activation of the mitogen-activated protein kinase $\mathrm{p} 38$ by human cytomegalovirus infection through two distinct pathways: a novel mechanism for activation of p38. J Virol 2000, 74:1158-1167.

58. Almeida-Porada G, Porada CD, Shanley JD, Ascensao JL: Altered production of GM-CSF and IL-8 in cytomegalovirus-infected, IL-1-primed umbilical cord endothelial cells. Exp Hematol 1997, 1997(25):1278-1285.

59. Gealy C, Denson M, Humphreys C, McSharry B, Wilkinson G, Caswell R: Posttranscriptional suppression of interleukin- 6 production by human cytomegalovirus. J Virol 2005, 79:472-485.

60. Billstrom Schroeder M, Worthen GS: Viral regulation of RANTES expression during human cytomegalovirus infection of endothelial cells. J Virol 2001, 75:3383-3390
61. Michelson S, Dal P, Dal Monte P, Zipeto D, Bodaghi B, Laurent L, Oberlin E, Arenzana-Seisdedos F, Virelizier JL, Landini MP: Modulation of RANTES production by human cytomegalovirus infection of fibroblasts. J Virol 1997, 71:6495-6500.

62. Baillie J, Sahlender DA, Sinclair JH: Human cytomegalovirus infection inhibits tumor necrosis factor alpha (TNF-a) signaling by targeting the 55-kilodalton TNF-a receptor. J Virol 2003, 77:7007-7016.

63. Hirsch AJ, Shenk T: Human cytomegalovirus inhibits transcription of the CC chemokine MCP-1 gene. J Virol 1999, 73:404-410.

doi:10.1186/1742-2094-9-95

Cite this article as: Alcendor et al:: Infection and upregulation of proinflammatory cytokines in human brain vascular pericytes by human cytomegalovirus. Journal of Neuroinflammation 2012 9:95.

\section{Submit your next manuscript to BioMed Central and take full advantage of:}

- Convenient online submission

- Thorough peer review

- No space constraints or color figure charges

- Immediate publication on acceptance

- Inclusion in PubMed, CAS, Scopus and Google Scholar

- Research which is freely available for redistribution 